\title{
Zakres badań nieniszczących i kryteria ich akceptacji wg norm zharmonizowanych z dyrektywą 97/23/WE w praktyce jednostki notyfikowanej 1433
}

\section{Scope of non-destructive testing and it's acceptance criteria according to standards harmonized witch the 97/23/EC directive in practice of notified body 1433}

\section{Streszczenie}

W artykule przedstawiono wymagania podano w normach zharmonizowanych z dyrektywą 97/23/WE dla urządzeń takich jak kotły, zbiorniki i rurociągi technologiczne odnośnie zakresu wymaganych badań nieniszczących, zasad badania złączy w niepełnym wymiarze i kryteriów akceptacji badań nieniszczących. Omówiono spotykane w praktyce jednostki notyfikowanej UDT błędy przy sprawozdaniach z wykonanych badań nieniszczących

\section{Warunki odniesienia}

Urządzenia ciśnieniowe wytwarzane na potrzeby rynku Unii Europejskiej muszą spełniać wymagania dyrektywy 97/23/WE [1], w skrócie PED. Dyrektywa ta dotyczy urządzeń o ciśnieniu wyższym od 0,5 bara. Podaje ona zasadnicze wymagania bezpieczeństwa, które muszą spełniać sprawdzane urządzenia. Wymagania te mają charakter ogólny i są precyzowane w normach zharmonizowanych z dyrektywą PED. Do oceny zgodności używane są także takie specyfikacje techniczne jak: WUDT-UC-2003, AD-Merkblatt 2000, przepisy ASME i inne.

Mgr inż. Łukasz Olichwer - Urząd Dozoru Technicznego, Szczecin.

\section{Abstract}

The paper shows the requirements set out in the standards harmonized witch Directive 97/23/EC for pressure equipment such as boilers, vessels and pipelines in scope of the non-destructive testing, testing rules of partial testing and non-destructive testing acceptance criteria. Discusses errors found in non-destructive testing rapports taken from common practice of the notified body UDT.
Specyfikacje AD-Merkblatt 2000 i WUDT-UC-2003 miały na celu zapewnienie ciągłości stosowania przez krajowych wytwórców dotychczasowych wymagań technicznych, jednak z zastrzeżeniem nierozwijania ich, czyli niewprowadzania do nich zapisów nowelizujących zgodnie z bieżącym rozwojem techniki. Przepisy ASME wykorzystywane są w Europie głównie w przemyśle chemicznym i petrochemicznym, pozostając warunkami konkurencyjnymi na tym rynku wytwórczym. Przepisy te nie są zharmonizowane z PED, stąd muszą być stosowane w myśl PED.

Poprawnie zastosowane normy zharmonizowane dają gwarancję spełnienia wymagań dyrektywy PED. Są konsekwentnie rozwijane przez poprawki i nowe wydania. Stopień ich wykorzystania w Polsce, wg doświadczeń jednostki notyfikowanej Urzędu Dozoru Technicznego, systematycznie rośnie. Potwierdza to 
raport dotyczący dyrektywy PED, w którym zauważa się, że stopień wdrożenia norm w poszczególnych krajach jest nierówny, lecz istnieje stabilność stosowania norm z tendencją wzrostową [2].

Podstawowe normy wyrobu zharmonizowane $z$ dyrektywą PED to: PN-EN 13445 dotycząca nieogrzewanych płomieniem zbiorników ciśnieniowych, PN-EN 13480 dotycząca metalowych rurociągów przemysłowych i odnoszące się do kotłów wodnorurowych i płomienicowo-płomieniówkowych odpowiednio: PN-EN 12952 i PN-EN 12053. Normy dla kotłów edytowane są przez ten sam komitet techniczny i z uwagi na brak drugiego wydania PN-EN 12053 jest ona pominięta w dalszej części artykułu.

Intencją komitetów technicznych przygotowujących normy było podanie pełnych wymagań technicznych dotyczących tych wyrobów. Umożliwia to wyprodukowanie urządzeń w pełni gotowych do pracy. Istnienie osobnych standardów dla poszczególnych rodzajów urządzeń ciśnieniowych wynika z istotnych różnic między tymi grupami urządzeń, takich jak: zagrożenia eksploatacyjne, funkcja, konstrukcja, wartość głównych obciążeń. Różnice dotyczą m.in. zakresu badań i kryteriów akceptacji badań nieniszczących. Są one efektem opracowywania norm przez różne komitety techniczne, w różnych latach i mogą być przyczyną pomyłek.

\section{Zakres badań nieniszczących wg norm zharmonizowanych}

Podstawowym wymaganiami bezpieczeństwa dyrektywy PED jest, aby połączenia nierozłączne i przyległe do nich strefy były wolne od wszelkich niezgodności powierzchniowych lub wewnętrznych, wpływających ujemnie na bezpieczeństwo urządzenia. Tak zdefiniowany warunek ma gwarantować jakość połączeń. Zakres badań określa liczbę spoin poddanych badaniom w stosunku do liczby spoin wykonanych i wyrażony jest w procentach. Zakres badań określany jest w wymienionych normach odmiennie. W normie zbiornikowej PN-EN 13445-5 [3] podstawowym kryterium podziału jest grupa badań zależna od współczynnika obliczeniowego złącza. W przypadku elementów poddanych badaniom nieniszczącym, które potwierdzają, że wszystkie złącza spełniają wymagania, współczynnik ten jest równy 1 . W przypadku urządzeń poddawanych losowym badaniom nieniszczącym współczynnik jest równy 0,85. Grubość obliczeniowa ścianki urządzenia powiększana jest w tym przypadku o 15\%, co zmniejsza ryzyko związane z losowym wyborem miejsc poddanych badaniom nieniszczącym. Wyodrębniono cztery grupy badań.

Grupy 1 i 2 dotyczą współczynnika obliczeniowego równego 1. Druga grupa zakłada niższy niż $100 \%$ zakres badań nieniszczących wynikający z udowodnionej praktyki wytwórczej. Ograniczeniem dla grupy drugiej jest wymóg wobec spoin wykonywanych w sposób zautomatyzowany z wybranych materiałów i o ograniczonej grubości.

Grupy badań dodatkowo dzieli się na podgrupy zależne od rodzaju materiału i jego grubości.

Ostatnia grupa dotyczy współczynnika obliczeniowego równego 0,7 i nie wymaga wykonywania badań nieniszczących. Użycie tej grupy badań jest jednak możliwe przy niewielkiej grubości ścianki, wybranych materiałach i zakresach temperaturowych.

W normie rurociągowej PN-EN 13480-5:2012 [4] zakres badań określony jest w zależności od kategorii urządzenia zgodnie z PED, grubości materiału i grupy materiałowej. Dla rurociągów projektowanych na media toksyczne i dla pary wodnej zakres badań ze względu na czynnik roboczy dodatkowo ulega powiększeniu.

W normie dla kotłów wodnorurowych PN-EN 129526:2011 [5] podział wynika z rodzaju elementu. Osobne tablice dotyczą walczaków, komór i elementów rurowych. Zakres badań w poszczególnych tabelach zależny jest głównie od rodzaju wykonywanej spoiny i grubości elementu.

Zakresy badań wysokoobciążonych elementów grubościennych ze stali trudnospawalnych zakładają we

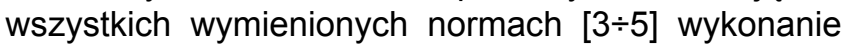
badań powierzchniowych i objętościowych w 100\%. Istotne różnice zaczynają się dla elementów mniej obciążonych i nie da się wyodrębnić reguły wspólnej dla wymienionych norm. Przykładem takich rozbieżności dotyczących zakresu badań jest analiza dla rurociągu o wymiarach 168,3 x $10 \mathrm{~mm}$ na parę o parametrach $7,5 \mathrm{MPa}$ i $500^{\circ} \mathrm{C}$ przed i za zaworem odcinającym, rozgraniczającym części urządzenia oceniane jako kocioł i jako rurociąg. Norma dla kotłów wodnorurowych wymaga wykonania minimum $10 \%$ badań objętościowych spoin obwodowych i $10 \%$ badań powierzchniowych spoin obciążonych ciśnieniem innych niż obwodowe, a norma dla rurociągów $100 \%$ badań powierzchniowych i objętościowych.

Normy zharmonizowane określają minimalny poziom bezpieczeństwa wyrobu. Projektant czy wytwórca w porozumieniu z inwestorem mogą zawyżyć zakres badania. $Z$ uwagi na wskazane różnice w wymaganym zakresie badania, zawarte w poszczególnych normach zharmonizowanych, źródłem informacji o tym zakresie musi być zwalidowana dokumentacja projektowa urządzenia. Sprawdzenie dokumentacji jest obowiązkiem producenta. W kategoriach wyższych niż II, z wyjątkiem modułu $\mathrm{H}$, także jednostka notyfikowana ma obowiązek sprawdzenia, czy zakres badania został przyjęty na poziomie nie niższym niż wymagany w warunkach odniesienia. Zakres badania zgony z zapisami w dokumentacji, ustalony $w$ zleceniu dla jednostki przeprowadzającej badania, jest jednoznaczną wytyczną. Także informacje o sposobie wyboru miejsca badania, gdy zakres jest niższy niż 100\% powinny być zawarte w zleceniu. Przy braku takiej informacji wybór złączy do badania powinien być oparty na wymaganiach norm. 


\section{Wybór miejsca badania o zakresie mniejszym niż $100 \%$ i procedura w przypadkach wystąpienia niezgodności}

Norma zbiornikowa [3] przy zakresie badań niższym niż $100 \%$ wymaga badania wszystkich skrzyżowań złączy doczołowych płaszczy ciśnieniowych i dennic na długości nie mniejszej niż 200 mm. Jeśli długość złączy wynikająca $z$ procentu wymaganego do zbadania jest niższa niż suma docinków badania skrzyżowań, obowiązuje wyższa wartość wynikająca z sumy długości. Także spoiny główne przecinające otwory lub spoiny główne przebiegające $w$ odległości nie większej niż $12 \mathrm{~mm}$ od otworów, powinny być badane na długości nie mniejszej niż średnica otworu.

W przypadku króćców badaniom poddawane są całe spoiny, a liczba zbadanych króćców wynika z procentu badań. Stwierdzenie niezgodności na spoinach badanych odcinkowo lub spoinach jednej z grupy króćców kwalifikuje całą spoinę lub całą grupę króćców jako niezgodną. Procedura powiększania zakresu badań zakłada zbadanie dodatkowej podwójnej długości spoin lub liczby króćców w przypadku niezgodności innych niż płaskie. Jeśli w tak wybranej próbce nadal występują niezgodności, należy zbadać całą spoinę lub grupę króćców. W przypadku stwierdzenia niezgodności płaskich badania dodatkowe od razu muszą objąć całą spoinę lub grupę króćców.

Norma dla kotłów wodnorurowych [5] przy zakresie badań niższym niż $100 \%$ wymaga, aby złącza były wybierane losowo i reprezentowały grupę. Grupą są złącza wykonane przez jednego spawacza lub operatora w oparciu o jedną procedurę spawania dla danego elementu. Jeśli wymagane jest przebadanie $10 \%$ złączy, należy zbadać każde $10 \%$ złączy wykonanych przez każdego ze spawaczy zgodnie z jedną instrukcją spawania. W przypadku wystąpienia spoin niezgodnych należy zbadać dodatkowo dwie spoiny elementu z grupy wykonanych przez tego samego spawacza wg tej samej procedury spawalniczej. Jeśli co najmniej jedna $z$ dodatkowej grupy spoin przekracza granice akceptacji, badaniom należy poddać 10 dodatkowych spoin. Procedura powiększania zakresu w przypadku występowania dalszych niezgodności powinna być kontynuowana aż do $100 \%$ spoin wykonanych.

Zapisy normy rurociągowej [4] są podobne do wymagań z normy dla kotłów wodnorurowych [5] z tą różnicą, że po stwierdzeniu niezgodności $w$ jednej $z$ dwóch dodatkowo badanych spoin wymaga się zbadania wszystkich spoin z danej grupy oraz badań wykonywanych na uzgodnionym między stronami, ale jak najwcześniejszym etapie wytwarzania. Wymóg taki pozwala wyodrębnić spawaczy wykonujących spoiny niezgodne i podjąć odpowiednie środki, zanim liczba wykonanych spoin będzie duża.

W każdym przypadku wystąpienia niezgodności w zakresie zleconym do badania jednostka badająca powinna ująć $\mathrm{w}$ dokumentacji badań stwierdzone niezgodności.
Decyzję co do trybu powiększenia zakresu badań nieniszczących podejmuje wytwarzający.

\section{Kryteria akceptacji}

Kryteria akceptacji określone są szczegółowo w cyto-

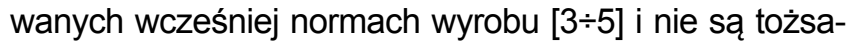
me. Różnice w poszczególnych standardach dotyczą nie tylko daty wydania normy określającej kryteria akceptacji, ale mogą obejmować także dodatkowe wymagania określone $w$ formie tablic. Taką sytuację obrazuje PN-EN 13480-5:2011 [4], która w tabeli 8.4.1 - NDT Techniki, metody i kryteria akceptacji, przywołuje do badań wizualnych zgodnych z PN-EN 970:1999 [6] jako kryteria akceptacji tabelę 8.4.2. Tabela 8.4.2 precyzuje który poziom jakości zgodnie z PN-EN ISO 5817:2009 [7] jest dopuszczalny dla poszczególnych kategorii rurociągu i wnosi dodatkowe uwagi. Określa także jako nieakceptowane niezgodności, dla których PN EN-ISO 5817:2009 [7] jest mniej restrykcyjna lub ich nie ujmuje. Należy pamiętać, że normy zapisane $z$ datą wydania w normie wyrobu obowiązują, mimo że dostępne są nowsze wydania tej normy lub zostały one wycofane.

W praktyce jednostki notyfikowanej UDT bardzo częstym przypadkiem są pomyłki w raportach dotyczących przyjętych do oceny kryteriów akceptacji. Jednostki badające, w raportach dotyczących $\mathrm{np}$. badań wizualnych spoin rurociągów technologicznych wg PN-EN 13480-5:2012 [5], potwierdzają poziom jakości B spoin zbadanych wg PN-EN ISO 5817:2009 [7]. W sytuacji rozszerzonych kryteriów akceptacji badań wizualnych stawianych przez PN-EN 13480-5:2012 [5] takie stwierdzenie nie potwierdza wypelnienia wymagań i nie może być zaakceptowane. Także forma zapisu w raporcie musi jednoznacznie stwierdzać wypełnienie kryteriów akceptacji. Jeśli kryteria akceptacji zostały zapisane w formie szerszej, np. klasa 2 wg PN-EN 12517-1:2008 [8] i wymagania tabeli 6.6.4-1 PN-EN 13445-5 2009 [4], to $w$ raporcie powinno być stwierdzenie o wypełnieniu tych wymagań $\mathrm{w}$ formie potwierdzenia lub zaprzeczenia. Często spotykanym błędem jest ocena odnosząca się do konkretnego radiogramu, dla której badacz potwierdza w tym przypadku tylko spełnienie wymagań klasy 2 wg PN-EN 12517-1:2008 [8]. Aby uniknąć sytuacji zwrotu dokumentów, dobrą formą jest uzgodnienie formy raportu z wytwórcą urządzenia na etapie zlecenia czy wykonywania badania.

Zakres badań nieniszczących i szczegółowe kryteria akceptacji powinny być umieszczone na rysunku wykonawczym urządzenia czy elementu, bo taką dokumentacją dysponują działy produkcyjne, które często odpowiedzialne są za zamawianie usług $w$ zakresie badań nieniszczących. Spotykana sytuacja parokrotnego powtarzania informacji dotyczącej zakresu badań i kryteriów akceptacji w opisach technicznych $i$ innych elementach dokumentacji technicznej urządzenia także często jest powodem pomyłek. 


\section{Wnioski}

Normy zharmonizowane $z$ dyrektywą PED wyznaczają poziom minimalnych wymagań przy ocenie zgodności urządzeń ciśnieniowych. Użycie norm stopniowo powiększa się wraz ze wzrostem świadomości wytwórców i wymaganiami rynku. Zakres badań nieniszczących urządzeń określony jest w poszczególnych normach wyrobów i z uwagi na różnice $w$ konstrukcji tych grup urządzeń oraz inne uwarunkowania w każdej z nich określony jest odmiennie, szczególnie w przypadku elementów mało obciążonych. Źródłem informacji o wymaganym zakresie badań musi być zwalidowana dokumentacja projektowa urządzenia. Każda z norm ma inaczej sformułowane kryteria akceptacji, co może być przyczyną błędów przy omawianiu badań. Jakość dokumentacji urządzenia i precyzja określenia zakresu i warunków akceptacji badań nieniszczących ma decydujący wpływ na możliwość popełnienia błędów w fazie wykonawczej badań. Raport z badań powinien jednoznacznie potwierdzać wypełnienie lub niewypełnienie kryteriów akceptacji. Uzgodnienie formy raportu na etapie badań może zmniejszyć liczby pomyłek i przyspieszyć realizację zlecenia.

\section{Literatura}

[1] Dyrektywa Parlamentu Europejskiego i Rady 97/23/WE z dnia 29 maja 1997 r. w sprawie zbliżenia przepisów prawnych państw członkowskich dotyczących urządzeń ciśnieniowych.

[2] Evaluation of the Pressure Equipment Directive Final Report October $2012 \mathrm{http}: / /$ ec.europa.eu/enterprise/dg.

[3] PN-EN 13445-5:2009 - Nieogrzewane płomieniem zbiorniki ciśnieniowe - Część 5: Kontrola i badania.

[4] PN-EN 13480-5:2012 - Rurociągi przemysłowe metalowe - Część 5: Kontrola i badania.

[5] PN-EN 12952-6:2011 - Kotly wodnorurowe i urządzenia pomocnicze - Część 6. Badania podczas wytwarzania - sporządzanie dokumentacji i znakowanie części ciśnieniowych kotłów.

[6] PN-EN 970:1999 - Spawalnictwo - Badania nieniszczące złączy spawanych - Badania wizualne.

[7] PN-EN ISO 5817:2009 Spawanie - Złącza spawane ze stali, niklu, tytanu i ich stopów (z wyjątkiem spawanych wiązką) - Poziomy jakości według niezgodności spawalniczych.

[8] PN-EN 12517-1:2008 Badania nieniszczące spoin - Część 1: Ocena złączy spawanych ze stali, niklu, tytanu i ich stopów na podstawie radiografii - Poziomy akceptacji.

\section{W następnym numerze}

Jerzy Czechowski, Alicja Pawełek, Krystyna Warsz

Podkładki ceramiczne do spawania nierdzewnych stali specjalnych w osłonie gazu obojętnego

Wojciech Czaplejewicz, Zdzisław Kondrat

Spawanie stali Boron 27 w stanie zahartowanym. Dobór spoiwa i parametrów spawania

\section{Janusz Czuchryj, Adam Pilarczyk}

Urządzenie UKS do kontroli szczelności złączy spawanych za pomocą próby pęcherzykowej z przyssawką próżniową

\section{Jacek Słania, Henryk Marcinkiewicz, Mariusz Kiełbik}

Technologia wykonywania konstrukcji osłony odzawałowej obudowy kopalnianej. Przygotowanie do spawania 